\title{
Civic Virtues and Civic Skills in Literary Texts: Content Analysis on Prevalence and Use, Grades Five to Eight Amharic and English Language Textbooks in Focus
}

\author{
Mengistu Anagaw (MEd) Yalemwork Mossu Yihenew Melese Alemakef Ewunetie \\ Abebaw Andargie \\ Debre Markos University, Ethiopia
}

\begin{abstract}
Albeit the debates on the usefulness of literary texts, discussions on specific purposes of integrating literary texts in language teaching materials is rare. This study, in a moment the world is witnessing serious deterioration of solidarity and respect for human diversity, attempts to discern how literary texts with civic virtues and skills [in grades five to eight English for Ethiopia and Amharic textbooks] have been presented from the 1970s to date. This purely qualitative content analysis study intends to demonstrate how civic virtues and civic skills are infused in language teaching literary texts. Using content analysis design, the frequency of literary texts is identified, the nature of tasks driven from literary texts is explored and the apparent changes across editions are discriminated. Careful content analysis of the literary texts and activities from it has been made to determine the civic virtues and skills.

A total of sixty three short stories, two riddles, fifteen fables and eight poems were found in thirteen different editions of the English language textbooks. Meanwhile the Amharic textbooks contain a total of twenty five poems, twenty two stories and two theatres and riddles. The findings reveal inconsistencies in the infusion of civic virtues and civic skills in literary texts of different editions. Some recent books explicitly state certain virtues and morals of stories requiring tasks and themes from literary texts while others leave it implicitly. Civility represents civic virtues that is not infused in any of the literary texts. Texts that instill patriotic feelings are common in textbooks used before 1991 while those used afterwards are significantly dire.
\end{abstract}

DOI: $10.7176 /$ JLLL/69-02

Publication date:June 30th 2020

\section{Introduction}

Literature, both in its written and oral form, has been serving a multitude of purposes. Especially in the foreign language teaching classroom, particularly during the period of grammar translation method, literary texts served as the best examples of language in use (Hall, 2005). These days, literary texts are used in foreign language classes for different purposes. For instance, Collie and Slater (1987:32) supported the use of literary texts identifying literature as "....an authentic material that deals with ever-present human concerns and ... touches emotions and invites personal involvement". Lazar (1993) indicated that using literary texts is a rewarding means of teaching foreign language skills. For Maley (1989:12) one of the great strengths of literature is its suggestive power for it invites readers to go beyond what is said to what is implied thereby generating language discussion.

Despite its long standing existence in EFL teaching materials, the use literary texts in the classroom has a number of challenges. Of these, selecting contextually appropriate and emotionally engaging literary texts and using them for well defined purposes are the most serious ones. Concerning this, Kachru in Brumfit and Carter (1986:140) stressed that only well selected, graded and contextualized literary texts can foster effective language learning environment. For McKay (1986) even the well selected, contextualized and graded literary texts could be ineffective to bring significant change on the students' language learning. Gajdusek (1988) cautions that lessons employing literary texts should not be 'fact-answer' sessions where students will look for pieces of information or try to mimic the structures used. Instead, students should be given opportunities to work with friends and express their views which according to Bredella and Delanoy (1996), can ensure getting the best out of literary texts.

Studies have attested contributions of using literary texts based on different approaches (cf. Timucin, 2001; Diana and Mohamed, 2007 and Tseng, 2010). These studies show the offerings of literary texts to development of language skills on one hand and approaches followed to arrive at those results, on the other. In the same vein, literature, as an educating material, plays a significant role in teaching students civic virtues and noble values as it often presents universal characters and themes that exemplify civility. For Lazar (1993) literature has the power to educate 'the whole person' as the aesthetic delight of literature serves to purify emotions and morals, and illumine the intellect. Moreover, literature is considered an efficient means to instill civic skills and virtues. For instance, Quigley (2000) underlines crucial role of literature in reinforcing civic virtues such as courage, tolerance, patriotism, integrity, respect...etc. arising from introducing students to literary texts that exemplify these virtues making the role of selecting appropriate texts exceptionally relevant. Moreover, engagement with literary texts urges and motivates the reader to unveil ambiguities and incompleteness of characters and plots (Kidd \&Castano,2013). The figurative aspect in literature adds impetus to perceiving it differently which enhances the 
students' critical thinking skills. (Lazar, 1993). However, studies that show the virtues and skills presumed in literary texts are scanty. Accordingly, this study intends to investigate the language teaching literary texts in alignment with the presumed civic virtues and skills. In other words, the need to analyze if literary texts in the different editions of language teaching materials are selected with civic virtues and skills in mind and if this is explicit in activities derived from literary texts in those textbooks is what initiated this study.

\subsection{Statement of the problem}

Education has often been geared towards a vision of enlightening citizens with basic values and principles - such as fairness, honesty, and respect for others - that would develop in learners a sense of social and personal responsibility, among other things. Without a certain level of adherence to these values, no community would survive and thrive. The role of literature in exposing students to characters and themes that accurately exemplify and truly represent civic virtues comprising courage, integrity, civility and patriotism as well as conflict resolution and negotiation and critical thinking and interpretation civic skills is undisputable.

Integration of literary texts meant for language teaching purposes has got momentum. Literary texts play an important role in enhancing communication competence by creating engagement, raising cultural awareness, and heightening motivation of students. In EFL context, literature is instrumental in engaging students' minds and feelings in meaningful communication (Sage, 1987).

For instance, a poem by Kebede Michael entitled Fanos ena birchiko should have touched and affected generations of learners and/ or readers and, because of its power, immediacy and beauty influenced many lives in unifying ways implanting some civic virtues and skills. Yet, integrating literature in a different context entails careful exploitation and thoughtful handling to put the students in a better position to benefit from it linguistically, culturally and motivationally.

Mehari (2016) explore the social and emotional development goals of English for Ethiopia Student Textbook Grade 9, this study reviews the content and activities of the textbook by searching for embedded peace values and prejudices. Language textbooks are media through which views, experiences and feelings are conveyed in artistic and inspiring ways (Balasooriya, 2001).

While literature lays a role in enhancing civic virtues and skills, it is not neither solely responsible for declines nor planned for such a purpose. Meanwhile, desire for an effective moral order has become an issue of both serious and urgent concern to all rationale minds in recent times all over the world (Quigley, 2000). The concern for a sound moral status is occasioned by the alarming rate of decline in the moral consciousness among the youth in Ethiopia. Decline of civic virtues and skills of the youth in terms of lack of integrity, civility and patriotic values have become exacerbating while skills of critical thinking and discussion are deteriorating recently. The way literary texts present these values might be partly responsible for the decline, for such texts exert immense influence on students' values and virtues. Hence, the desire to discern how literary texts having civic virtues and civic skills are used in different editions of language teaching textbooks grades five to eight used from the 1970s up to the present days.

\subsection{Research questions}

$\checkmark \quad$ How many of the literary texts in textbooks are infused with civic virtues and civic skills?

$\checkmark \quad$ How are tasks based on literary texts having civic virtues and civic skills presented?

$\checkmark \quad$ How does use of literary texts having civic virtues and civic skills vary across editions?

\subsection{General objective}

The study basically intends to demonstrate how civic virtues and civic skills are exerted in language teaching literary texts used from grades five to eight from the 1970s up to the present days. More specifically, the study intends to:

$\checkmark$ To identify frequency of literary texts that are infused with civic virtues and civic skills.

$\checkmark$ To explore presentation of tasks from literary texts exerting civic virtues and civic skills.

$\checkmark$ To discern changes across editions of textbooks in the use of literary texts.

\subsection{Scope of the Study}

The use of literary texts can be enjoyed when teachers adopt contextually appropriate approaches based on specified purposes (Diana and Mohamed, 2007). One among the pivotal preconditions for this is the selection and presentation of appropriate literary texts from which meaningful tasks can be adopted. Hence, this study is delimited to investigating how civic virtues and civic skills are exerted in Amharic and English language teaching literary texts in grades five to eight used from the 1970s up to the present days. Content analysis on literary texts in language teaching textbooks together with the objectives stated in the curriculum will be used to collect data needed for the study. 


\subsection{Significance of the Study}

The investigation of presentation of literary texts with civic virtues and skills in language teaching textbooks might be significant for three major reasons. Firstly, the study might benefit practitioners who are using literary texts and activities from the literary texts in classrooms by indicating possible limitations and strengths of the selection of literary texts in relation to enhancement of civic virtues and skills. Secondly, the study might indicate possible ways of exploiting literary texts to inculcate civic virtues and civic skills.

\subsection{Operational Definition of Terms}

1. Literary texts: might refer to a wide Variety of literary genres that invite imaginative involvement and thinking (Delanoy, 1997). However, as far as this study is concerned, the term is used to refer to genres provided within the grade levels. It is used to refer to short stories, poems, riddles and tales only.

2. Civic virtues: the use of literary texts can enhance different virtues of readers. However, it restricted to courage, tolerance, integrity and respect in this study.

3. Civic skills comprise individual abilities including communication and organizational abilities that allow citizens to use time and money effectively in political life. In this study, it is operationalized to refer to conflict resolution and negotiation skills, critical thinking and interpretation skills, among other things.

\section{RESEARCH METHODOLOGY}

The study is purely qualitative content analysis intending to demonstrate how civic virtues and civic skills are demonstrated in language teaching literary texts of English and Amharic language teaching textbooks. The design is expected to enable researchers to identify frequency of literary texts and explore the nature of tasks driven from literary texts thereby discriminating changes across editions and comparing Amharic and English textbooks in using literary texts having civic virtues and skills.

\subsection{Research design}

As of Krippendorf, K (2004) content analysis is the intellectual process of categorizing qualitative textual data into clusters of similar entities, or conceptual categories, to identify consistent patterns and relationships between variables or themes. Content analysis is the most appropriate technique for this study as it enables researchers to study human behavior in an indirect way (Frankel, Wallen \& Hyun, 2012). According to Frankel, Wallen \& Hyun (2012) there are some valuable steps involved in content analysis that are adopted in this study. The first thing a content analysis research should do is determining objectives for carrying out the study. specifying the unit of analysis follows identification of the objective where in literary texts of any sort in language teaching materials of grades five to eight since the 1970 s are considered. The themes of those literary texts in terms of instilling civic virtues and skills is the focus of this study and a criteria for selection of texts. To that end, literary materials in text books are purposively (on the grounds of relevance for the purpose) selected for the study. The unit of analysis is text level for the theme of a literary text is often the source of civic virtues and skills. In doing content analysis on literary texts, both the manifest and the latent contents (Frankel, Wallen \& Hyun, 2012) on civic virtues and civic skills are considered.

\subsection{Validation and trustworthiness}

The researchers has made utmost efforts to ensure the validity and trustworthiness of findings. To that end, the researchers access and select literary texts from different edition of the Amharic and English language teaching textbooks. The selected texts are read by five EFL expert teachers [three from literature and two civics] to determine the predominant use of the text in terms of instilling civic virtues and skills. The same procedure has been followed in determining the nature of activities driven from literary texts. Discussion of findings is made accordingly in a way that ensure maximum dependability (Lincoln \& Guba, 2019). To that end, the final draft of the study report is be by the raters of the civic virtues and skills associated with literary texts.

\subsection{Data Analysis Techniques}

Both qualitative and quantitative data analysis is carried out. The frequency of literary texts in English and Amharic language teaching textbooks looks for frequency counts while the nature of activities driven from those literary texts needs exploration followed by summative quantitative analysis. Hence, the data is generated from literary texts and it is necessary to code and organize themes accordingly. The qualitative data from textbooks is organized and presented thematically. 
Table 1: the literary texts and its distribution

\begin{tabular}{|c|c|c|c|c|c|c|c|c|c|c|c|c|c|c|c|c|c|c|c|c|}
\hline \multirow{3}{*}{ 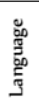 } & \multirow{3}{*}{ Genre } & \multicolumn{19}{|c|}{ Grade } \\
\hline & & \multicolumn{4}{|l|}{5} & \multicolumn{5}{|l|}{6} & \multicolumn{5}{|l|}{7} & \multicolumn{5}{|l|}{8} \\
\hline & & 1978 & 1996 & 2007 & $\cdot$ & 1976 & 1978 & 1990 & 1996 & 2007 & 1974 & 1978 & 1997 & 2000 & 2007 & 1973 & 1990 & 1997 & 2007 & \\
\hline \multirow{4}{*}{ 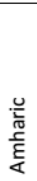 } & poem & 2 & - & - & - & 2 & 2 & 1 & 2 & & 1 & - & 4 & 1 & 4 & 1 & 2 & 2 & 1 & \\
\hline & story & 1 & 4 & 1 & - & & & 4 & 3 & & - & - & 1 & 1 & 1 & 1 & 3 & 2 & - & \\
\hline & fable & & & & & & & & & & & & & & & & & & & \\
\hline & Theatre & - & - & - & - & & & & & & & & & & & & & & 1 & \\
\hline \multirow{5}{*}{$\begin{array}{l}\text { 点 } \\
\text { 离 } \\
\text { 㟧 }\end{array}$} & poem & & & & & & & & & & & & & & & & & 2 & & 4 \\
\hline & story & 3 & 6 & 6 & 2 & 2 & 6 & & & & 5 & 4 & 2 & & & 9 & 9 & 3 & 5 & \\
\hline & fable & 3 & & & & 4 & 1 & & & & 2 & 2 & 1 & & & & & & & 2 \\
\hline & Theatre & & & & & & & & & & & & & & & & & & & \\
\hline & riddle & 1 & & & & & & & & & & & & & & & & & & \\
\hline
\end{tabular}

\section{RESULTS AND DISCUSSIONS}

The study basically intends to demonstrate how civic virtues and civic skills are exerted in language teaching literary texts used from grades five to eight from the 1970s up to the present days. More specifically, the study intended to explore frequency of literary texts that exert civic virtues and civic skills along with presentation of tasks from literary texts. The study discerns changes across editions of textbooks regarding the use of literary texts. As a result, a purely qualitative content analysis is carried out to demonstrate how civic virtues and civic skills are demonstrated in language teaching literary texts of English and Amharic language teaching textbooks. The forthcoming section presents a holistic discussion of the literary texts used in different editions of Amharic and English language teaching textbooks. In other words, texts from different editions are cited to demonstrate the civic virtues and skills that can be developed from using the texts. Thus, the first section presents frequency of literary texts. The second section focus on civic virtues and civic skills that can be developed by using the literary materials

\subsection{Distribution Literary texts in language teaching textbooks}

4.1.1. The distribution of literary texts in grade eight English language textbook

\begin{tabular}{|c|c|c|c|c|c|}
\hline Edition & Genre & title of the literary text & unit & page no & Moral (theme) \\
\hline \multirow[t]{7}{*}{1983} & story & landlord Gultie is caught alive & 1 & $04-07$ & \multirow[t]{3}{*}{ Courage (to fight injustice) } \\
\hline & story & landlord Gultie is caught alive & 2 & $14-15$ & \\
\hline & story & landlord Gultie is caught alive & 3 & $21-23$ & \\
\hline & story & the first awakening & 8 & $70-71$ & \multirow{3}{*}{$\begin{array}{l}\text { conflict resolution and negotiation } \\
\text { skills }\end{array}$} \\
\hline & story & the first awakening & 9 & $80-81$ & \\
\hline & story & the first awakening & 10 & $90-91$ & \\
\hline & story & the living whisper & 13 & $133-136$ & Patriotism \\
\hline \multirow[t]{7}{*}{1991} & story & landlord Gultie is caught alive & 1 & 5 & \multirow[t]{3}{*}{ Courage to fight injustice } \\
\hline & story & landlord Gultie is caught alive & 2 & $14-15$ & \\
\hline & story & landlord Gultie is caught alive & 3 & $21-23$ & \\
\hline & story & the first awakening & 8 & $70-71$ & \multirow{3}{*}{$\begin{array}{l}\text { conflict resolution and negotiation } \\
\text { skills }\end{array}$} \\
\hline & story & the first awakening & 9 & $80-81$ & \\
\hline & story & the first awakening & 10 & $90-91$ & \\
\hline & story & the living whisper & 13 & $133-136$ & Patriotism \\
\hline \multirow{4}{*}{2007} & poem & school & 6 & 75 & Courage \\
\hline & poem & eggs & 6 & 76 & Critical thinking skills \\
\hline & Fable & the ant and a grasshopper & 7 & 80 & Courage \& critical thinking skills \\
\hline & story & never give up & 7 & 83 & Courage \\
\hline \multirow[t]{3}{*}{1998} & story & Taming a husband & 1 & 3 & $\begin{array}{l}\text { Critical thinking and problem solving } \\
\text { skills }\end{array}$ \\
\hline & story & A clever solution & 14 & 58 & \\
\hline & story & FIRE on the mountain & 16 & $66-67$ & \\
\hline \multirow{6}{*}{2008} & Poem & My mother & 2 & $7-$ & \\
\hline & Poem & Home sweet home & 3 & & Civility \\
\hline & fable & The black snake and the eggs & & & $\begin{array}{l}\text { critical thinking and interpretation } \\
\text { skills }\end{array}$ \\
\hline & Poem & Ethiopia's delicacy & & & Patriotism \\
\hline & fable & The hare and the monkey & & & $\begin{array}{l}\text { Critical thinking and problem solving } \\
\text { skills }\end{array}$ \\
\hline & Poem & Good results & & & \\
\hline
\end{tabular}


As for the grade 8 English textbooks studied, the frequency of literary texts seem reasonable. Textbooks from 1978 up to the present time has been looked into. The 1978-1983 editions contain contains seven literary texts of which all are short stories. The 1983-1991 edition likewise contains the same literary texts. The 2007 and 2008 editions, similarly include six literary texts apiece.

One interesting finding is the choice of genres and themes of literary texts. The literary texts in grade eight textbook from 1978 up to 1991 reflect the then sociopolitical order. The short story 'landlord Gultie is caught alive' for instance teaches exploitation of the poor tenants and how peasants associate to demolish that system. Similarly, 'the first awakening' is a title given to a short story in which the exploitation of factory workers is exposed and strategies to address it are highlighted. The other literary text is entitled 'the living whisper'. It narrates the deeds of a brave female soldier named Kibrie. The story enshrines her motto 'we must defend our motherland and our revolution' as the living whisper. On the other hand, the 2007 and 2008 editions of the grade eight textbook make a different look into text selection. Bothe the 2007 and 2008 editions contain poems, stories and fables. The poems in the 2007 edition are entitled 'school' and 'egg' whereas 'my mother, home sweet home, Ethiopia's delicacy and good results' are poem titles in the 2008 edition.

At surface level, selection of literary texts in the 1978-1991 editions reflect sociopolitical bases in which civic skills and civic virtues needed at the time are infused while the texts afterwards look dire in that respect.

4.1.2. Distribution Literary texts in grade eight Amharic language teaching textbooks

\begin{tabular}{|c|c|c|c|c|c|}
\hline Edition & genre & Title & Unit & Page & Moral \\
\hline \multirow[t]{2}{*}{1973} & Short story & กิลไว3 & 3 & $8 \_13$ & Integrity \\
\hline & Poem & $\hbar^{\sigma 904}$ & 15 & $90-95$ & Patriotism \\
\hline \multirow[t]{4}{*}{1996} & Story & 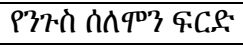 & & & critical thinking skills \\
\hline & story & $\rho 7 C$ TG & & & Patriotism \\
\hline & poem & 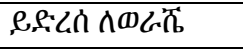 & & & critical thinking skills \\
\hline & Poem & ヤभけ & & & - \\
\hline \multirow[t]{2}{*}{2007} & Poem & ดUภฯ ๆTqD年 & 4 & $67-69$ & - \\
\hline & Theatre & 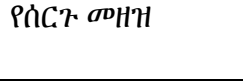 & 10 & $218-$ & $\begin{array}{l}\text { Negotiation and critical } \\
\text { thinking skills }\end{array}$ \\
\hline
\end{tabular}

The Amharic language grade eight textbooks that has been considered in this study include the ones published in 1973, 1996 and 2007. The 1973 edition contains a poem and a short story. The 1996 edition includes two poems and two stories. Conversely, the 2007 edition contains cultural oral poems and a theatre in three scenes. The theatre is about extravagant practices relating to marriage ceremonies.

4.2. Civic virtues: courage, integrity, civility and patriotism

Civic virtue refers to the way good citizens should behave and function in a society. Civic virtue as used in this study includes morals of literary texts that comprise courage, integrity (honesty), civility (politeness) and patriotism among other things.

Courage is the resolve to act virtuously, especially when it is most difficult. It is acting for the good, when it would be much easier not to this time. A good instance of a literary text that instills courage is landlord Gultie is caught alive. The story narrates how organized tenants and peasants got the courage to overthrow and defeat the landlord system. The moral in the story is to keep on courageous in the face of danger, and chooses to overcome fear and act according to their values. It is not fearlessness, recklessness, or rashness. 
In addition, he did many cruel things to them; he made some of the tenants wash his family's feet every evening; he made others wash the clothes of his wife and his children. He made several of the tenants' wives fetch water in turn from far away places and rivers. Gultie made the remaining tenants work on the farmland until late in the evening. Even worse, he made some of the tenants' children shepherds; some, herders, and the others, servants. Three years ago, when the 'Abiot' started, he ran away to the bush with his elder son and with some of the innocent tenants who had been misled by him. 5

Courage is a well-considered, wise, and brave decision to behave constructively despite the fear, discomfort, or temptation. The extract below demonstrates how one should unite and plan act procedurally to demonstrate ones courage.

However, the village dwellers, tne peasus... the surrounding area and they became more united than angrier and angrier. they set out their zemecha plan, prepared their war from the people's militia chairman, the leader of the search squad.

Courage is a strength drawn from a wise balance between the weaknesses of cowardice and recklessness. It is the discipline to act on wisely-chosen values rather than an impulse. One can learn from the villagers' physical courage, (Perseverance or diligence (endurance) or moral courage to fight injustice.

3. What was Ato Gultiolite wealthy?

3. What made Ato do to the poor answers) 4. What did he do to tosibie answers)

5. Why did many of the happy?

6. When did they become hun away to the bish?

7. When did Ato Gultie run to the bush?

8. Why did he ran away and the villagers

9. Why did the peasan?

10. Why did the people's militia polish their id rifles? 
However activities drawn from the literary text are used, efforts to relate the inherent virtues and skills into their lives is not made.

As of the above tasks, there is no question of inferences. Most of the items ask students for information from the story. The items in the other sections of the story adopt the same pattern.

A fable entitled 'the ant and a grasshopper' in the 2007 edition of the grade eight textbook has a similar civic virtue to illuminate. The second paragraph of the fable is excerpted below.

"I am helping to save food for "a rainy day"* and you should do the
same," said the ant. "Why worry about a rainy day? We have plenty of
food for now," said the grasshopper, but the ant went on its way and
continued to work hard. When a time of shortage came the grasshopper
had no food and found itself dying of hunger. It saw the ant eating corn
and grain from the store it had collected when food was abundant. Then
the grasshopper knew.

* a time of shortage

Moral: It is best not to delay work. Don't put off un you can do today.

In this fable, the assumption is for students to learn courage to do tasks in the right time and before the rainy days come. Of course, the moral is explicitly stated after the fable.

The Amharic language grade eight textbook lacks literary texts of any type that can instill courage among civic virtues. Neither of the 1973, 1996 or the 2007 edition contains such texts.

Integrity is the practice of being honest and showing a consistent and uncompromising adherence to strong moral and ethical principles and values. Integrity is regarded as the honesty and truthfulness or accuracy of one's actions. While the English language textbooks do not have literary texts with this virtue, the 1973 edition of Amharic language text book contains a short story entitled 'shilingen'. It is about a woman who long for her son. The woman was saving money earned from selling papaya to a train travelers. The person who wanted to buy the papaya returned it claiming the papaya was spoiled. The woman asked for the change she gave him but he felt the woman was misleading him first by attempting to sell rotten papaya and then by asking for a change. He got her shilling in his pocket afterwards. He felt sorry for his deeds.

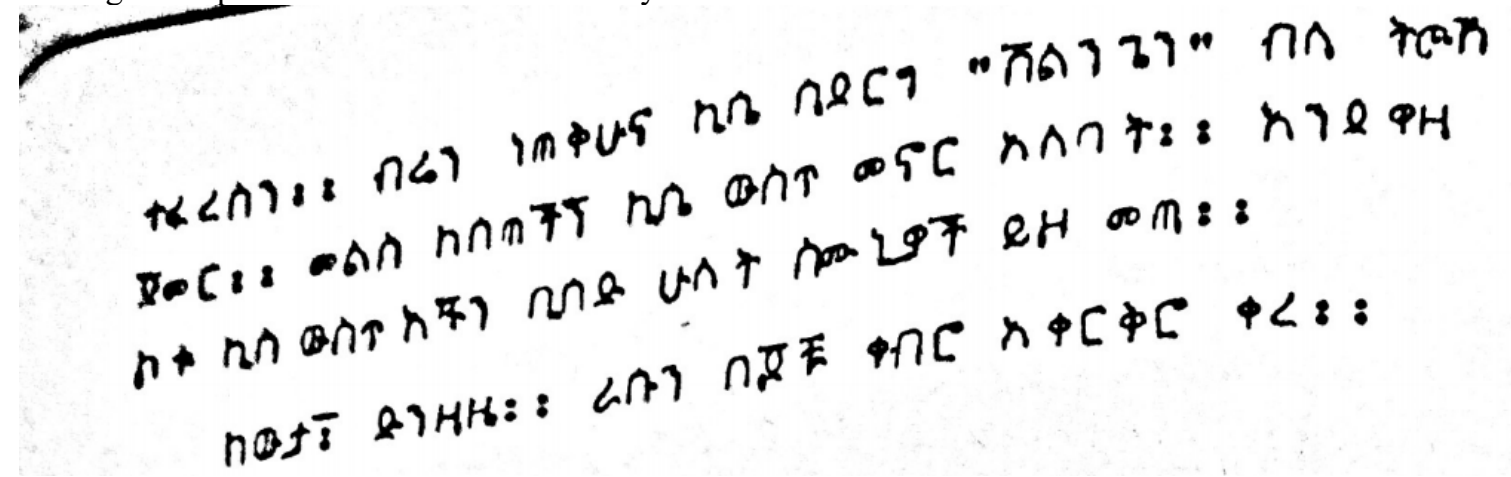

as we can learn from the Above excerpt, Integrity can stand in opposition to hypocrisy, in that judging with the standards of integrity involves regarding internal consistency as a virtue, and suggests that parties holding within themselves apparently conflicting values should account for the discrepancy or alter their beliefs. Conversely, the disrespect he showed caused him regret which can be used as a lesson and source of developing unconditional respect. 


\section{OADT $\cap$ IP}

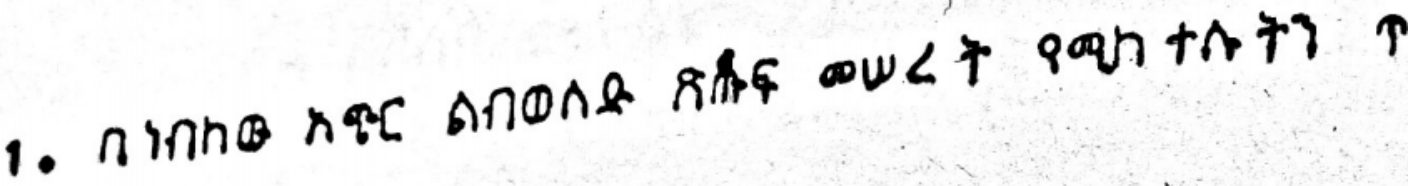 กRimt osti: :

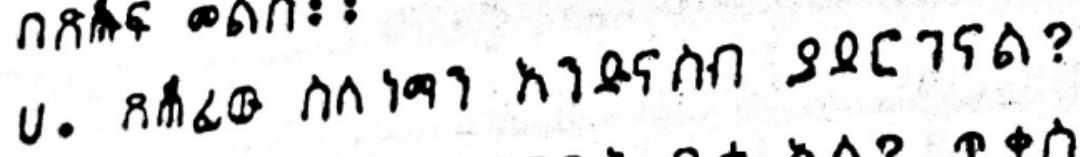 \\ n. K18392\& se<7กt กt $n \Lambda$ ? $p \phi \lambda:$ : \\ h. hibient se<7nt กt nก?

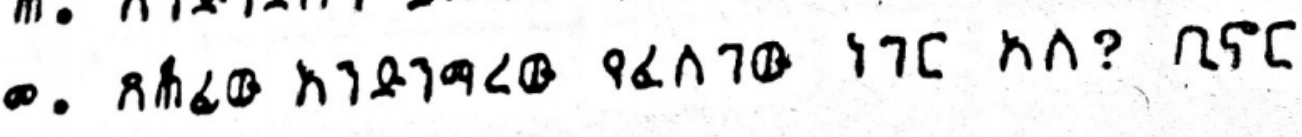 \\ iB hi?}

1. กบด?

2. $\mu[q \uparrow ?$

3. P८ी?

The activities excerpted above can illustrate the virtues the text is chosen to illustrate. The students are expected to discern the lessons they need to learn from the text of which culture, civility and morality are explicitly asked.

Civility and politeness represent a certain propriety in manners and speech that tends to please and demonstrates the respect while interacting with each other. It is a virtue that is not prominently and significantly addressed in literary texts or activities derived from the texts.

Patriotism or national pride is the feeling of love, devotion and sense of attachment to a homeland and alliance with other citizens who share one's ethnic, cultural, political or historical aspects. A number of literary texts inculcating patriotism and national pride are used especially in those used before 1991. In the 1983 English textbook a short story entitled 'The Living Whisper' is presented. The short story is about the heroic death of a female soldier named Kibrie. This story in general arouses national pride to defend ones motherland. The moto of the deceased hero was infiltrated everywhere in every soldier echoing 'we must defend our motherland and our revolution.' 


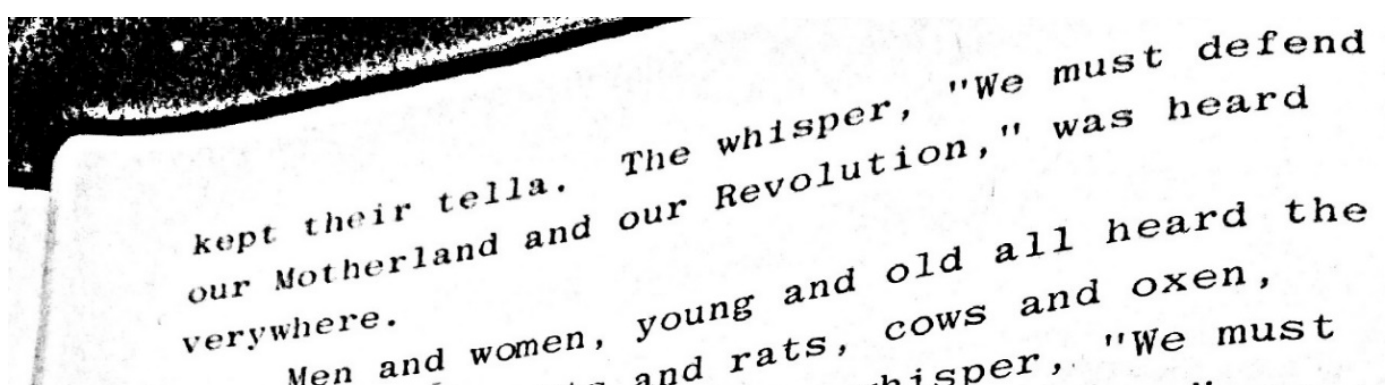

Men and women, young and cows and "We must whisper. Even cats heard the whisperion." donkeys and horses ho moving and defend our Motherlan so persuasive, who heard it The whisper wars that those who loud and so exiting to the in whispers but in motherland forceful voice, "We must defend

forceful voice,
and our Revolution:"
Today they hear and say it as they heard and said it in order to achieve the just aim both the

dead and the living have already set.

The story further goes on the reap attention of cats and rats, cows and oxen, donkeys and horses figuratively representing union of different personalities of individuals in the effort. Nonetheless, the activities resulting from the material do not accentuate the virtue either explicitly or implicitly. As the literary text is used based on the information based approach, comprehension questions are asked. The students are asked to comprehend the text but items requiring virtues from the text are not used.

\section{Comprehension}

A. ANSWER THE FOLLOWING QUESTIONS ORALLY AND

THEN IN WRITING.

1. Name three of the words that are used to describe Kibrie.

2. Why were the other soldiers very pround of

in her?

3. What was the most important sentence in Kibrie's short speech?

4. How did Kibrie die?

5. What exactly was the living whisper?

i. BELOW YOU WILL FIND THE MEANING OF SOME OF THE WORDS IN THE PASSAGE. READ THE MEANINGS. THEN, GO BACK TO THE PASSAGE AND FIND THE
WORDS THAT MATCH THE MEANINGS.

The other material that can slightly instill national pride is a poem entitled 'Ethiopia's delicacy' in the 2008 edition of grade eight textbook. The poem louds Ethiopia's delicious dish. The poem, written by a foreigner adores composition of the national dish. Yet the activities prepared from the text are fact finding type. 
The literary texts in the Amharic textbook present patriotic virtues in meaningful ways. The 1996 edition of grade eight Amharic textbook presents a story entitled ' $\rho 7 C$. $\zeta \zeta$ ' that narrates the story of a graduate and his adoptee. The adoptee took the boy and take care of him till his graduation. On his graduation, the woman wanted him to get married but his desire to serve uneducated compatriots.

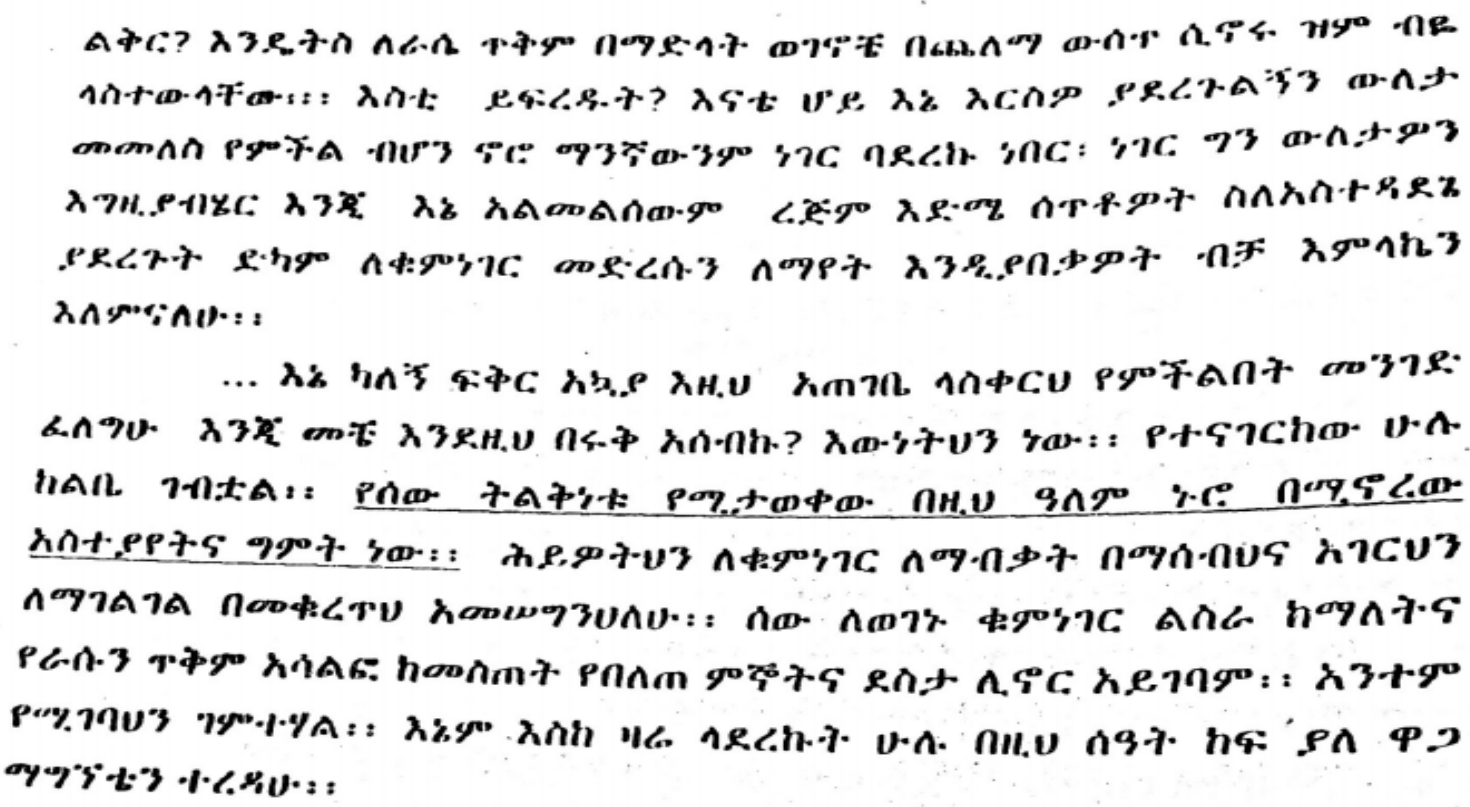

4.3. Civic skills: conflict resolution and negotiation skills, critical thinking and interpretation skills Civic skills include the abilities to communicate, organize to influence policies and practices, and think critically. Patrick (2002) identifies two important categories of civic skills: participatory skills (conflict resolution and negotiation) and cognitive skills (the capacity to analyze and interpret). For Kirlin (2004), "basic communication skills develop in early and middle childhood while the more sophisticated critical thinking skills appear in midlate adolescence" (ibid., p. 8) though "instruction and exposure" matter a lot to develop skills (ibid. p. 9). Literary texts play a critical role in instilling such skills.

Negotiation refers to exchange of ideas with the intention of changing relationships. Successful negotiation requires compromise in which both parties must gain something, and both parties must lose something. In a successful negotiation, everyone wins and the objective should be agreement, not victory. One good instance of negotiation and conflict resolution as a civic skill is a passage entitled 'the first awakening' in the 1973 edition of the grade eight textbook. The story is about a factory owner and his employees who suffer from exploitation. The exploitation caused conflict.

$$
\text { Then another speaker said: "Yes, what our }
$$

friend says is true. We are all miserable, but we are afraid to do any thing about it. If we oppose the owner one by one, we will lose our jobs. This has happened to many of our comrades here and in other factories. We have to unite and struggle for justice. We must organize ourselves. If we do that, we can destroy this unjust system.

Planning negotiation and knowing whether one is in a win-win or win-lose situation is vital. As of the above extract, the workers agreed on their misery and proposed to unite and struggle for justice not to lose their jobs one by one as part of their plan. In such a win-lose situations, they are proposing win-win solutions defying alternatives that allow the owner to declare victory. 


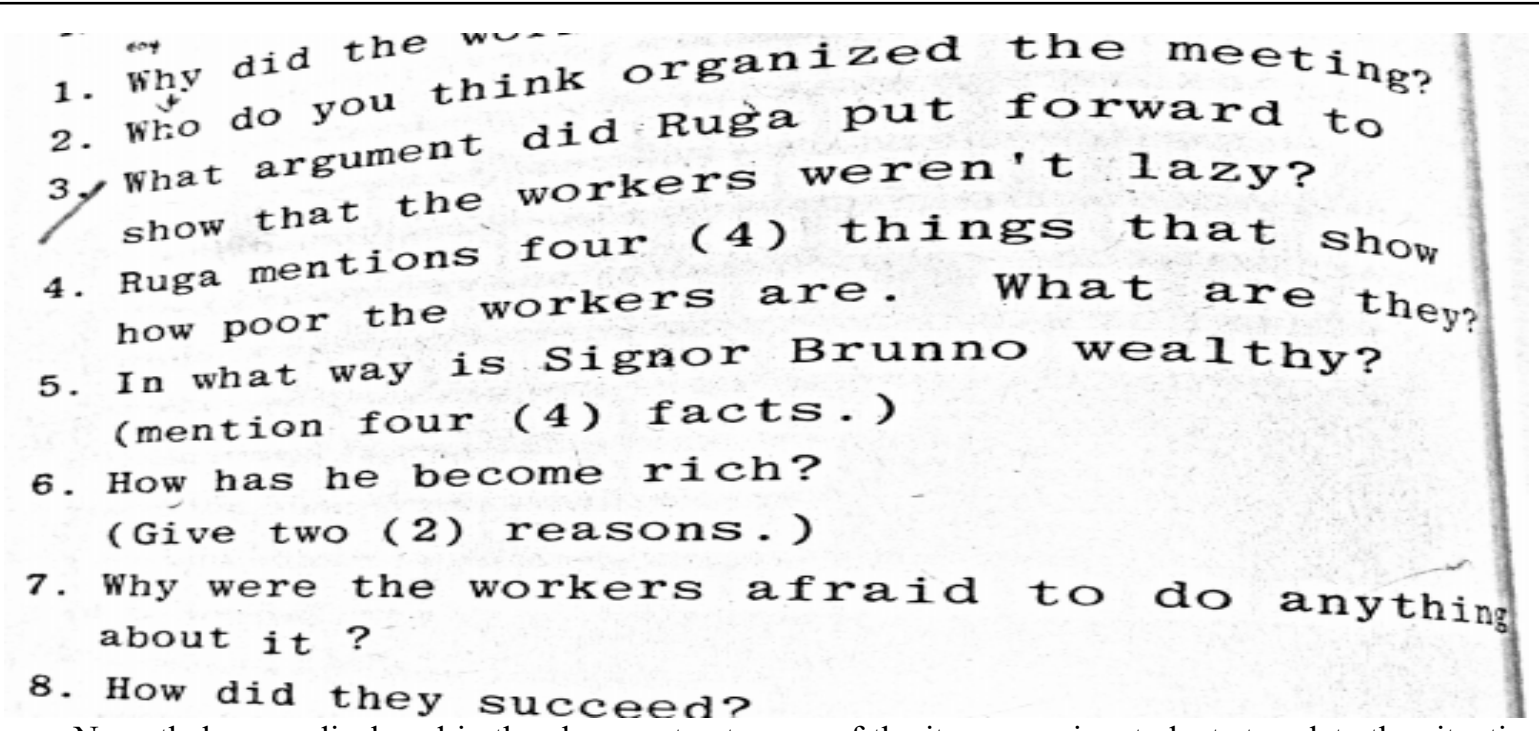

Nevertheless, as displayed in the above extract, none of the items require students to relate the situation to real circumstances to make negotiations when conflicts arise. The text is used to fact finding questions which do not require students be in the shoes of the workers to make negotiations.

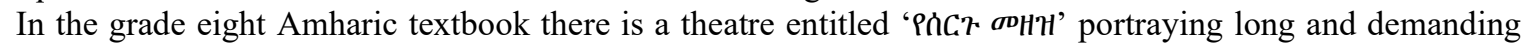
negotiation and conflict resolution skills.

Critical thinking which involves the ability to think in an organized and rational manner in order to understand connections between ideas and/or facts (Facione, 1998) includes interpretation, analysis, inferences, explanation and self-regulation which helps deciding what to believe. For instance, the following extract can reveal how critical thinking and problem solving skills are infused in a short story entitled taming a husband.

$$
\begin{aligned}
& \text { The old man laughed. "A woman who is brave enough to take } \\
& \text { three hairs from a living lion doesn't need a charm to tame } \\
& \text { her husband. Make him love you in the same way as you got the } \\
& \text { lion's hairs. Just remember: Be patient. Much of what is } \\
& \text { good comes slowly." }
\end{aligned}
$$

Critical thinking and interpretation sub-skills include categorization, decoding significance, and clarifying meaning. An example of interpretation is recognizing a problem and describing it without bias. In this literary text, students can appreciate how far solving a family problem might be, especially comparing it to the magnitude of taking hairs from a living lion. Analysis in critical thinking and problem solving includes examining ideas, detecting arguments, and analyzing arguments as sub-skills of analysis. In the story, readers can infer similarities and differences between approaches to solve the problem. The new way to get hairs from a living lion involved patience and care and the same efforts were suggested to tame a husband. As part of the evaluation of the credibility and logical strengths and weaknesses of claims, the woman is suggested to be patient. Inference identifies elements needed to draw reasonable conclusions, to form conjectures or hypotheses, to consider relevant information, and then to deduce the consequences from the selected relevant information, data or facts.

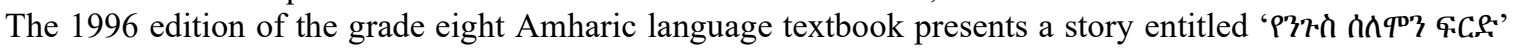
where in a bee and a fly went to King Solomon to get wisdom. Both are sent to kill their leader before getting the wisdom, but while the fly thought poor and decided to kill its leader the bee thoughtfully decided to die itself than kill its leader. The bee selflessly thought on similarities and differences between approaches to solve the problem and decided to die than kill a leader so that bee family wouldn't be leaderless.

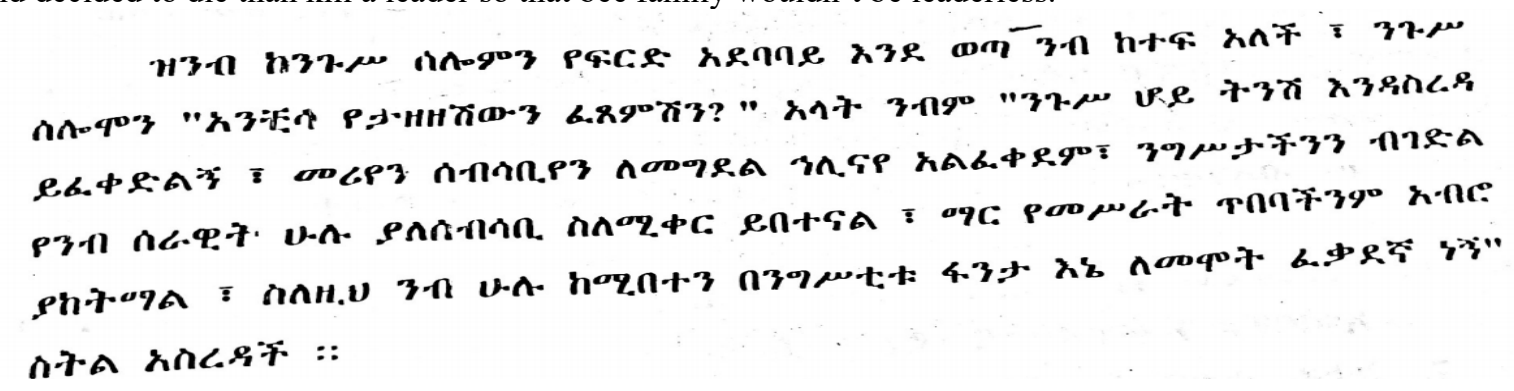

5. Conclusions and recommendations

The study intends to demonstrate how civic virtues and civic skills are infused in language teaching literary texts 
used from grades five to eight from the 1970s up to the present days. To that end, the study identified frequency of literary texts that are infused with civic virtues and civic skills, explored presentation of tasks from literary texts exerting civic virtues and civic skills and discerned changes across editions of textbooks in the use of literary texts. A content analysis on the infusion of civic virtues and civic skills in language teaching literary texts has been carried out. Careful content analysis of the literary texts and activities from it has been made to determine the civic virtues and skills.

Accordingly, the following conclusions are drawn.

1. The frequency of language teaching literary texts infused with civic virtues and civic skills in grades five to eight has been checked. As of the( thirteen) Amharic and (fifteen) English editions of the textbooks, the number and type as well as relevance of literary texts has regressed in recent editions.

2. The content analysis demonstrates that activities drawn from literary texts do rarely require development of infused civic virtues and skills. However, some recent textbooks explicitly state moral of the literary texts.

3. Literary genres infused with different civic virtues and skills were frequent in earlier editions. But those texts do not require tasks that can exploit the virtues and skills. The findings reveal inconsistencies in the infusion of civic virtues and civic skills in literary texts of different editions. Some recent books explicitly state certain virtues and morals of stories requiring tasks and themes from literary texts while others leave it implicitly. Civility represents civic virtues that is not infused in any of the literary texts. Texts that instill patriotic feelings are common in textbooks used before 1991 while those used afterwards are significantly dire.

Suggestions are made for the improvement of fusion of civic virtues and skills in language teaching literary materials, accordingly. Firstly, practitioners who are using literary texts and activities from the literary texts in classrooms should identify limitations and strengths of the selection of literary texts in relation to enhancement of civic virtues and skills and adapt them accordingly. Secondly, literary texts should be exploited and included in language teaching materials to inculcate civic virtues and civic skills. Finally, further studies intended to reconsider such materials from different perspectives should be carried out by scholars.

\section{REFERENCES}

Bagherkazemi, M. \& Alemi, M.,2010.Literature in the EFL/ESL Classroom: Consensus and Controversy. Linguistic and Literary Broad Research and Innovation, 1(1):1-12.

Barnett, M. 1991. Language and Literature: False Dichotomies, Real Allies. ADFL Bulletin, 22(3): 7-11.

Barnett, S., Berman, M. \&Burto,W. 1961. An Introduction to Literature. Fiction Poetry Drama. Little Brown and Company, Inc, Canada. 491P.

Bredella, L. \& Delanoy, W. (eds), 1996. Challenges of Literary Texts in the Foreign Language Classroom. Tiibingen: Gunter Narr.254P.

Brumfit, C., and Carter, R., 1986.Literature and Language Teaching. Oxford University Press. 289P.

Carter, R. 1986. Linguistic Models, Language and Literariness: Study strategies in the Teaching of Literature to Foreign Students. Pp. 110-132. In Brumfit, C. \& Carter, R. (eds.). Literature and Language Teaching. Oxford: Oxford University Press.

Christine, F. 1995.The Effect Of Literature-Based Approach on the Reading Attitudes of Male Students in the Third and Fifth Grades, ERIC Document, Paper Presented At the mid western educational research association. Chicago. 19p.

Collie, J. \& Slater S., 1987. Literature in the language classroom: A resource book of ideas and activities. Cambridge: Cambridge University Press.

Delanoy, W., 1997. Teacher Mediation and Literature Learning in the Language Classroom Position Paper, University of Klagenfurt, Austria. Accessed on 22 March 2010 URL:wilistepley.com/LCS/articles/wd.htm

Delanoy,W., 2005. Dialogic Model for Literature Teaching. ABAC Journal 25 (1): 53-66.

Diana, H. \& Mohammed, A., 2007. Approaches Employed By Secondary School Teachers to Teaching the Literature Component in English.UniversitiKebangsaan Malaysia, JurnalPendidikdan Pendidikan.22, 1-23.

Erkaya, O., 2005. Benefits of Using Short Stories in the EFL Context. Asian EFL Journal 8, 1-13

Fauziah, A., 2008. Presage, Context, Process and Product: Influencing Variables in Literature Instruction in an ESL Context.GEMA Online Journal of Language Studies, 8(1):1-21.

Floris, F., 2004. The Power of Literature in EFL Classrooms. Petra Christian University, Surabaya-Indonesia. KCATA, 6(1):1-12.

Gajdusek, L.,1988.Toward Wider Use of Literature in ESL: Why and How.TESOL Quarterly, 22(2): 227-277.

Halim,H., 2006. Students' Preferences in Learning Literature Component of the Malaysian Secondary School English Language Syllabus.Journal Pendidikan, ---:141-155

Hall, G. 2005. Literature in Language Education. Research and Practice in Applied Linguistics. New York: Palgrave Macmillan. 278p.

Hirvela, A. 1996. Reader-Response Theory and ELT. ELT Journal,5(2): 127-134.

Hismanoglu, M., 2005. Teaching English through Literature. Journal of Language and Linguistic Studies, 1 (1):52- 
64.

Kachru, B. 1986. 'Non-Native Literatures in English as a Resource for Language Teaching'. Pp. 140-149. In: Brumfit, C. and Carter, R. (Eds.), Literature and language teaching. Oxford: Oxford University Press, London.

Kim, M., 2004. Literature Discussions in Adult L2 learning. Language and Education, 18(2):145-166.

Kramsch, C. 1985. Literary Texts in the Classroom: A Discourse. The Modern Language Journal, 69(4):356-366.

Krippendorff, K. (2004). Content Analysis: An Introduction to its Methodology. London: Sage.

Langer, J. 1997. Literacy Acquisition through Literature. Journal of Adolescent and Adult Study, 40, 602-

Lazar, G., 1993. Literature and Language Teaching: A Guide for Teachers and Trainers. Cambridge: Cambridge University Press. 267p.

Martin, A. \& Laurie, I., 1993. Student Views about the Contributions of Literary and Cultural Content to Language Content at Intermediate Level. Foreign Language Annals 26(2):188-207.

McKay, S., 1986. Literature in the ESL Classroom. Pp. 191-198. In: C. Brumfit \& R. Carter. (Eds.). Literature and Language Teaching. Oxford University Press, London.

Moody, H., 1971. The Teaching of Literature in Developing Countries. London, Longman Group Ltd.

Nystrand, M. \&Gamoran, A., 1991. Instructional Discourse, Student Engagement, and Literature Achievement. Research in the Teaching of English, 25(3):261-290.

Özlem, A., 2007. Poetry in Primary School EFL Classroom: A Language Based Approach. MA Thesis. University of Çukurova, The Institute of Social Sciences.111p.

Qareeballah, H. \&Seyd, S., UD. Teaching Language through Literature: A diagnostic study on the Teaching of English as a Foreign Language. Accessed on February 29, 2010 URL: http://repository.ksu.edu.sa/jspui/handle/123456789/4906.

Radhika, O., 1991. Literature in the Language Classroom. UniversitiKebangsaan Malaysia, Kuala Pilah. The English Teacher. Accessed on May 13 2010.URL: http://www.melta.org.my/ET/1991/main6.html

Rosli T., 1995. Teaching literature in ESL: the Malaysian context. Kuala Lumpur: PenerbitUniversiti, Pertanian Malaysia. 203P.

Rush, P., UD. Behind the Lines: Using Poetry in the language classroom. Retrieved on January, 21, 2010 from URL: http://library.nakanishi.ac.jp/kiyou/gaidai(30)/05.pdf.

Savvidou, C., 2004. An Integrated Approach to Teaching Literature in the EFL Classroom. The Internet TESOL Journal, 10(12). Retrieved on January, 23, 2010, from URL: http://iteslj.org/Techniques/SavvidouLiterature.html

Sell, R., 2005. Why Teach Literature in the Foreign Language Classroom? Journal of Research and Innovation in the Language Classroom. --86-93.

Short, M., 1996. Stylistics 'upside down': using stylistic analysis in the teaching of language and literature. Pp 4165. In Carter, R., McRae, J. (Eds.), Language, Literature and the Learner: Creative classroom practice. London: Longman.

Sivasubramaniam, S., 2006. Promoting the Prevalence of Literature in the Practice of Foreign and Second Language Education: Issues and Insights.Asian EFL Journals8(4): 254-273.

Squire, J., 1994. Research in Reader Response: Naturally Interdisiplinary. In Ruddell, R. Ruddell M., and Singer, H. (eds.). Theoritical Models and Processes of Reading $4^{\text {th }}$ edn. Newark, DE: international reading association.

Tayebipour, F. 2009. In Defence of Teaching Literature to EFL Students in the Era of Globalization. pp. 213-219 In: Hang, L., R. Rubdy, \&Alsagoff(Eds.). (2009). Englishes and Literatures-in-English in a Globalised World: Proceedings of the 13th International Conference on English in Southeast Asia.

Tseng, F., 2010. Introducing Literature to an EFL Classroom: Teacher's Presentations and Students' Perceptions. Journal of Language Teaching and Research, 1(1): 53-65.

Timucin, M., 2001. Gaining Insights into Alternative Teaching Approaches Employed in an EFL Literature Class. CAUCE, Revista de Filología y suDidáctica, 24, 269-293.

Vera, Z., 1991. Literature as Study and Resource: The Purposes of English Literature Teaching at University Level.RevistaAlicantina de EstudiosIngleses, 4 (1991): 163-75.

Wang P., 2009. The Application of Integrated Literature Instruction in Freshman English Teaching. Sino-US English Teaching, 6(9): 1-11.

Widdowson, H. G. (1975). Stylistics and The Teaching Of Literature. London: Longman. 140 p. 